\title{
KÜSZÖBÖN A DIGITALIZÁCIÓ: A KONTROLLEREKKEL SZEMBEN TÁMASZTOTT KOMPETENCIA-ELVÁRÁSOK VÁLTOZÁSA - SZAKIRODALMI ÁTTEKINTÉS
}

\section{DIGITALIZATION IS AROUND THE CORNER: THE CHANGING COMPETENCE EXPECTATIONS OF CONTROLLERS - LITERATURE REVIEW}

\author{
Doszpoly Petronella ${ }^{1}$ \\ ${ }^{1}$ Pénzügyi és Számviteli Intézeti, Gazdaságtudományi Kar, Miskolci Egyetem, Magyarország
}

\author{
Kulcsszavak: \\ digitalizáció \\ automatizáció \\ kontrolling \\ Keywords: \\ digitalization \\ automation \\ controlling
}

\begin{abstract}
Összefoglalás
A szakirodalom "digitalis átalakulásnak", vagy "disruptív technológiának" nevezi az innováció azon tulajdonságát, ahogyan és amilyen gyorsan felforgatnak egy-egy iparágat, társadalmi alrendszert. Mindez a szervezet egészét érinti, különös tekintettel a pénzügyi funkcióterületekre. Ezen területek egyrészről a megfelelő döntéstámogatás biztositása nyomán végig követik a digitális transzformáció okozta változásokat, másrészrôl ezek nyomán új lehetôségek adódnak, amelyek révén hatásosabbá lehet válniuk e területeknek maguknak is. Ezen környezeti változások indokolttá teszik az ezen munkaterületeken dolgozókkal szemben támasztott kompetencia-elvárások és feladatkörök alakulásának beható vizsgálatát. Jelen tanulmány célja, hogy releváns szakirodalom áttekintésén keresztül bemutassa, hogy a digitalis átalakulás a jelenben miként formálja a kontrolling gyakorlatot, illetve az ezen munkaterületen dolgozókkal szemben ezzel párhuzamosan milyen új munkaeröpiaci igények indukálódnak.

\section{Abstract}

In the literature the way innovation shakes an industry or social subsystem shows up as 'digital transformation', or 'disruptive technology'. Digital transformation impacts the whole company, especially finance and accounting. These function areas, on one hand, are following the changes brought about by digital transformation, while supporting decisionmaking process, and, on the other hand, new opportunities are opening up to make these areas more effective. These environmental changes demand an in-depth examination of the development of competency expectations and responsibilities of employees working these function areas. The aim of this paper is to determine how the revealed processes and tendencies affect the organizational and the individual level, and how the expectations of the future controller change.
\end{abstract}




\section{Bevezetés: a digitális átalakulás és annak munkaerôpiaci vetülete}

Jelenleg a negyedik ipari forradalom, illetve az „ipar 4.0” korszakát éljük. Utóbbi elnevezést (Industry 4.0) 2011-ben használta először a német kormányzat, amikor meghirdette 2020-ig tervezett iparfejlesztési programját, ám mára már világszerte önálló fogalommá vált. Heynitz és szerzőtársai (2016) szerint az Ipar 4.o úgy írható le, mint valami, ami a digitalizáció segítségével integrálja a vállalat értékteremtő tevékenységeit és az értékteremtési láncot. [8] Másként fogalmazva, az eddig izoláltan múködő termelési egységek integrált, automatizált és optimalizált termelési folyamattá olvadnak össze, amelynek következtében átalakul a beszállítók és az ügyfelek közötti viszony. A digitális gazdaság mára szorosan összefonódott az Ipar 4.0 fogalommal. A digitális megoldások, az automatizálás és a rendszerek összekapcsolását a magyar köznyelvben is leginkább Ipar 4.0 néven említik. [6, 11] Geissbauer és szerzőtársai (2016) az Ipar 4.0 megvalósítását szolgáló eszközök alkalmazásának három szintjét értelmezik. Az első szinten a termelési folyamat digitalizációja zajlik (IoT - internet of things, platformok, mobileszközök, felhőalapú szolgáltatások); a másodikon ennek partnerkapcsolatokra történő kiterjesztése történik (üzleti modell és vevőelérés digitalizációja magas szintű ember-gép interfészeken keresztül); majd pedig új termék-szolgáltatás portfóliók kidolgozása (big data elemzések, többszintű vevői interakciók, vevőprofil-alkotás). A szerzők az Ipar 4.o célját úgy látják, az valamennyi fizikai eszköz digitalizációjára törekszik, hogy egy „digitális ökoszisztémában” egyesítse azokat az értékteremtési láncban együttmúködő partnerekkel együtt. [7] Mikro szinten, az új technológiákat alkalmazók arra számítanak, hogy jelentősen csökkentik az anyag- és energiaráfordításaikat, növelik a kapacitásainak kihasználtságát és gyorsabban lesznek képesek piacra vezetni a változó keresletnek megfelelő új termékeiket. Az i4.o megoldások makrogazdasági hatásait tekintve ugyanakkor nincs konszenzus a közgazdász szakmán belül. A szakirodalom által leginkább vitatott témák közé tartozik - a termelékenységnövekedésre, illetve a globális értékláncok szerkezetére gyakorolt hatás mellett - a foglalkoztatásra gyakorolt hatás is.

A technológiai változások kétféle módon hatnak a foglalkoztatásra: egyrészről beszélhetünk ún. kreatív rombolásról (creative destruction), amely akkor következik be, mikor a technológia kiváltja az élő munkát, így a munkaerő kínálatot más területekre kell koncentrálni. Másrészről az így felszabaduló munkaerőt más, nagy termelékenységú ágazatok szívják fel, amelyet kapitalizációs hatásnak (capitalisation effect) nevezünk. A gyakorlatban a fő kérdés az, hogy a két ellentétes irányba ható folyamat közül melyik lesz erôsebb a jövőben: a létrejövő munkahelyek száma kiegyenlíti-e a megszűnő munkahelyekét, illetve hosszútávon fenntartható-e ez az egyensúly.[4] A gépek általi helyettesíthetőség ellen az adott foglalkozást az védheti legjobban, ha annak végzése során finom érzékelés és mozgás; kreatív intelligencia (eredetiség, művészet); társadalmi intelligencia (érzékenység, tárgyalási gyakorlat, együttműködési készség) szükséges, ezeken a területeken ugyanis a tevékenységek gépesítése technikai akadályokba (engineering bottlenecks) ütközik. Egyes vélemények szerint ugyanakkor a gépek már nemcsak rutinszerü feladatok végzésében válthatják ki a humánerőforrást, mára ugyanis képessé váltak bizonyos összefüggések felismerésére, ezáltal pedig az emberi tanítás nélküli tanulásra. Korábbi példák tanulmányozásával mintázatokat ismernek fel, amelyeket aztán más területeken alkalmaznak. Ezt pedig azt eredményezi, hogy az ügyfélszolgálati munkától az orvosi diagnózis felállításáig a gépek alkalmazása egyre szélesebb körben válik elterjedtté.

\section{Digitális átalakulás a kontrolling területén}

A digitalizáció terjedésével az elmúlt években felerősödtek a kontrolling szakma megszűnéséről szóló félelmek. Ennél azonban sokkal több olyan tényező van, amelyik amellett szól, hogy a kontrolleri munka az eddiginél is fontosabbá válik. Annak ellenére, hogy egyes tevékenységeket a későbbiekben nem kontrollerek végeznek majd, mások esetében adott az automatizálás lehetősége, ezek mellett a korábbiaktól eltérő feladatok is megjelennek, melyekhez új, digitális módszereket kell kipróbálnia.

Isensee és szerzőtársai (2019) a kontrolling folyamatokat három alapvető csoportba sorolják: irányítás (governance); tervezés és termelés (design and production); és üzleti 
partnerség (business partnering). [9] A szerzők véleménye szerint a jövő kontroller szerepkörét elsősorban ezek közül kettő, az irányítás végrehajtása és a business partnering fogja alkotni, ugyanis a robotizált folyamatautomatizálás (RPA) megoldások a tervezés és termelés területén rendkívül előnyösnek ígérkeznek. RPA-val történő automatizálásra kiválóan alkalmasak például a következő tevékenységek:

- adatok / információk összevezetése különböző adatforrásokból;

- ellenőrzések és validálások végrehajtása;

- standard jelentések elkészítése előre megadott struktúrák szerint és eltérések felismerése, illetve

- egyszerű értelmezések előállítása.

Az RPA megoldásokkal járó egyik legfóbb előny a folyamatosság. A rendszer folyamatosan, munkaidőhöz való igazodás nélkül, megfelelő ütemezéssel akár több, különböző folyamaton is képes dolgozni, amely az egyes tevékenységek hatékonyságának növelése mellett, annak időigényét is képes csökkenteni. Azzal pedig, hogy a folyamatok a munkaidőn túl is müködtethetők, a rendszerek terhelése is kiegyenlítettebbé válhat. [1]

$\mathrm{Az}$ adatelemzés terén napjainkban megjelenő fő kérdés az, hogyan tudjuk a fellelhető hatalmas mennyiségü adattömeget nyereségesen hasznosítani. Mára már az operatívabb szinteken is adatok alapján, azaz adatvezérelten hozunk döntéseket, illetve nagyobb hangsúly van az adatok prediktív, előre mutató elemzésén, mint azok leíró jellegén, mindez pedig alapjaiban határozza meg az adatelemzési folyamatokat.[16] A „business analytics” egy olyan elemzési folyamatot jelent, amely a deskriptív (leíró) elemzésektől a prediktív (előrejelző) elemzésen át a preskriptív (előíró) elemzésekig jut el. Horváth (2016) meglátása szerint, a jövőben az elemzési folyamat az IT szakember, az adattudós (data scientist) és a kontroller együttmúködésével valósulhat meg.[8] A hatalmas mennyiségben rendelkezésre álló adatot másrészről egyre nagyobb feladat fogyasztható, könnyen értelmezhető formába hozni, miközben ezzel párhuzamosan egyre nagyobb értéket képvisel, hogy egy összetett jelenséget minél gyorsabban értelmezzünk, érthetóen és tömören adjunk tovább olyan módon, hogy közben szelektáljuk az információkat fontosságuk, újdonságuk alapján. A megoldást az önkiszolgáló üzleti intelligencia (self-service business intelligence, SSBI) alkalmazások nyújthatják. Az önkiszolgáló üzleti intelligencia az adatelemzés egy olyan megközelítése, amiben képessé teszi az üzleti felhasználókat, hogy hozzáférjenek az adatokhoz, illetve elemezni tudják azokat, anélkül, hogy szükségszerűen rendelkezniük kellene statisztikai elemzési, üzleti intelligencia (BI) vagy adatbányászati technikákkal. Ezáltal a végfelhasználók üzleti döntéseket hozhatnak a saját elemzéseikből, miközben mindez a kontroller munkáját is lerövidíti azáltal, hogy nem az adott riport alatt lévő adatbázis kialakításával és megformázásával kell eltöltenie az ideje nagy részét, ehelyett olyan egyéb feladatokra tudnak koncentrálni, mint az eltérések mögött húzódó okok feltárása, amelyek nagyobb hozzáadott értéket jelentenek az egész vállalat számára.

\section{A kontroller feladatkörök és kompetenciaelvárások alakulása a digitalizáció hatására}

A kontrollerek szerepe a digitalis megoldások következtében szükségszerűen változni fog. Fenyves, Fenyves- Tarnóczi, Musinszki - Gyenge - Lipták, illetve Blumné és Zéman (2014) úgy ítéli meg, hogy összességében csökkenés és azon belül a hagyományoshoz képest a tevékenységek hangsúlyaiban is jelentős átstrukturálódás várható, ahogyan ezt a következő ábra is szemlélteti. [2, 3,4, 12] 


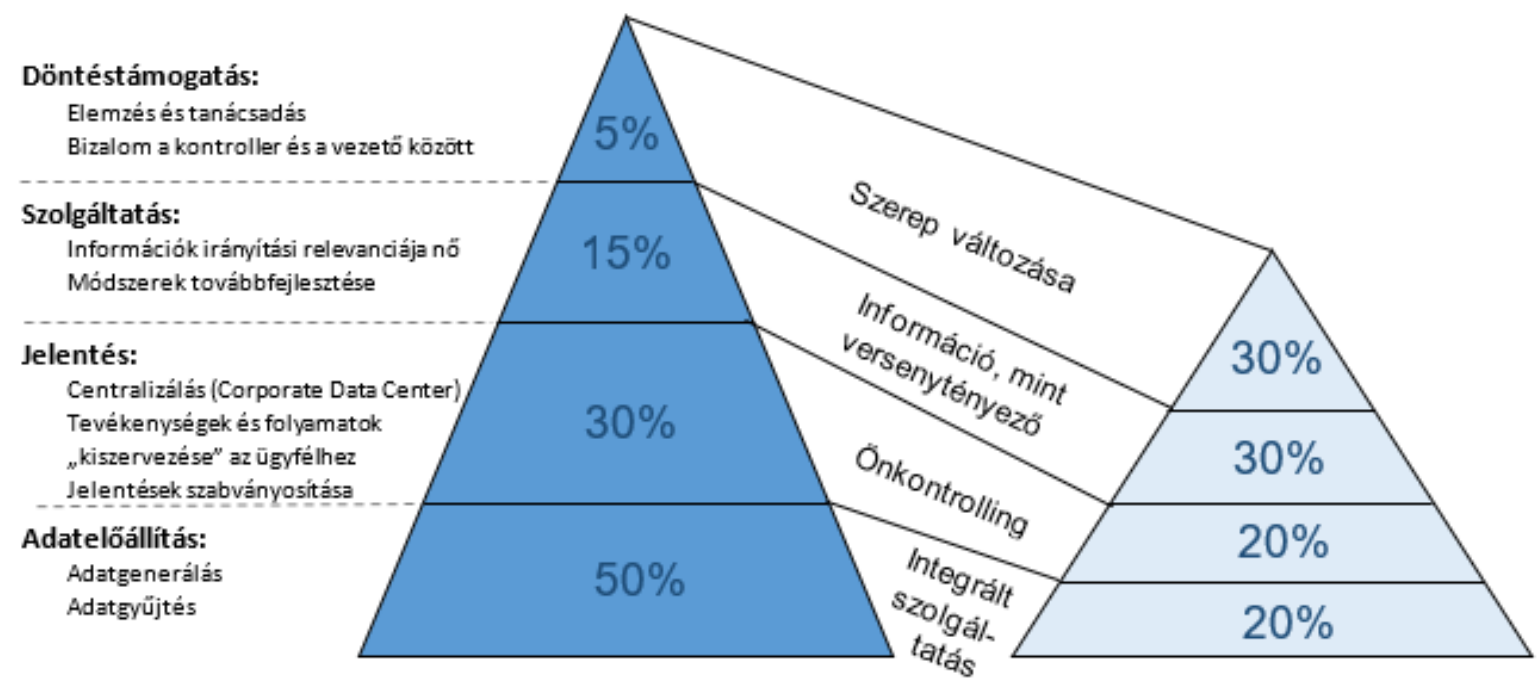

1. ábra: A kontrollerek átalakuló szerepköre Forrás: [2] alapján

A munka alapja a helyzetértékelés, a teammunka, a változáskezelés és a projektmenedzsment. Az analitikus gondolkodásmód egyre inkább felértékelődik, a riportok technikai előállításán túl, azok értelmezésében is a vezetőket kvalitatív információkkal kell támogatni. A kontrolling szaktudás mellett előtérbe kerül az ügyfélorientáltság és tanácsadói kompetencia, amely szintén arra utal, hogy azon túlmenően, hogy a kontroller megbízhatóan szolgáltatja a vállalati beszámolókat, ezek értelmezéséhez egyfajta tanácsadói szerepkört is szükségszerűen be kell töltenie.

A tanácsadói kompetenciák igényének növekedése mellett az IMA kutatásai arra hívják fel a figyelmet, hogy a jövőben a kontroller és a szervezet többi fö funkcióterülete közötti kölcsönhatás egyre inkább felerősödik. A szervezet egy 2013-mas kutatása során azt találta, hogy a kontrollerek várhatóan szoros kapcsolatban fognak állni az információs technológiával (44\%) és a belső ellenőrzéssel (43\%), emellett szintén bizonyos szintű információcserét folytatnak a minőségbiztosítás, a HR, az értékesítés és a gyártó területekkel. Ezzel egyben felerősödik az ún. „T-alakú” képességek iránt igény is, vagyis a képességek mély és széles birtoklása. A „T” betű horizontális vonala szimbolizálja a szélességet, amely ebben az esetben nagyobb hangsúlyt fog kapni. Ez az a képesség, hogy különböző területeken, azok szakértőivel együttmúködjünk, és több mint egy szakterületen tudjuk alkalmazni a tudásunkat (adott esetben egy projekt során projektkontrollerként). Ezekhez sorolják a kommunikációs és interaktív képességeket, vagyis a kapcsolatok menedzselését a folyamat különbözőrésztvevői között. A „T” betű vertikális vonala a szakértelem mélységét mutatja, melynek részei között jelenik meg a funkcionális tudás, a problémamegoldó attitűd, vagy az elemzési képesség

A terhelhetőség és munkabírást azonosította az IFUA Horváth \& Partners hazai kompetencia kutatása a második legfontosabb kompetenciaként, amelyet a szerzők az egyre növekvő információs igényekkel magyaráznak. Ma már egyre kevésbé jellemző az, hogy a kontrolling havi ciklusokban, havonta egy nagyobb terhelés mellett dolgozik, ugyanakkor sokkal inkább az állandóan változó, folyamatos információs igények kielégítése terheli le a szervezetet. A szerzők várakozásaival ellentétben, az üzleti tudás, az üzlet értése nem jelenik meg a kulcskompetenciák között, a rangsor 12. helyére szorult. Ennek a kompetenciának a jelentőségét Magyarországon elsősorban a termékportfólió és a vállalati stratégia ismeretével azonosítják, sokkal kevésbé terjed ki az iparági ismeretekre, versenytársakra vagy akár a vállalati értékláncra. A szerzők véleménye szerint ez a fejlődési utat is kijelölheti a magyar kontrollerek számára. [13]

Az új digitalis megoldások nyomán változó feladatkörökkel a kontrollerek szerepkörei között is egyre inkább egyfajta hangsúlyeltolódás figyelhető meg. A szakirodalom által elkülönített három szélsőséges szerepkör közül (hagyományos, számvitel-orientált kontroller; 
jövőorientált "belső tanácsadói” kontroller; és mentrendszer-orientált kontroller [10]) egyre nagyobb hangsúlyba kerül egyfajta stratégiai „business partneri” szerepkör, vagyis a klasszikus kontrolleri szerepek betöltése mellett (ellenőri, elemzői szerepek) a kontrollereknek egyre inkább a vállalatvezetés tanácsadójaként és döntéshozatali folyamatok aktív résztvevőjeként kell, hogy jelen legyenek a szervezeten belül. [14] Emiatt pedig nagyfokú proaktivitás kell jellemezze a vállalatvezetés kiegészítő partnereként. A tervezési folyamat megszervezésén, az információk rendelkezésre bocsátásán túl, tanáccsal szolgálnak a vezetők felé, annak érdekében, hogy a vállalatirányítás racionális alapjait biztosítsák. A PwC 2017. évi tanulmánya szerint tévhit, hogy minden kontrollernek egyben business partnerré kell válnia a jövőben. A „hagyományos” szerepet betöltő kontrollerek ugyanis hasonlóan fontos szerepet töltenek be a szervezet életében, azon keresztül, hogy biztosítják a pénzügyi funkciók olyan minőségi követelményeinek teljesülését, mint a helyesség, teljesség, időszerűség. Ugyanakkor az is kérdéses, hogy egy kontroller egyáltalán képes-e mindkét szerepet betölteni egyszerre, ugyanis a feladatok ezen két kombinációja rendkívül összetett. Riportáláskor a kontrollernek független fél álláspontját kell képviselni, miközben business partnerként a döntéshozatali folyamat résztvevőjeként van jelen a szervezetben. [15]

Losbichler, az International Group of Controlling (IGC) vezetője szerint: „Az ember a feladatokkal együtt nő.” Véleménye szerint lényegét tekintve a kontrolling csekély mértékben változott, az üzleti sikerhez még mindig a célkitűzés, a tervezés és az irányitás ciklusa szükséges. Ugyanakkor a környezeti változások okozta új kompetencia-elvárások megjelenése nyomán, a szervezeteknek tudatában kell lenniük a kontrollerek változó szerepkörével, azon kompetenciákkal, amelyekkel szükségszerüen rendelkezniük kell, annak érdekében, hogy képesek legyenek támogatni az ezekhez való alkalmazkodást.

\section{Köszönetnyilvánítás}

Ezúton szeretnék köszönetet mondani Musinszki Zoltán tanár úrnak, aki témavezetőként a munkámat felügyelte, és értékes szakmai tanácsokkal látott el.

AZ INFORMÁCIÓS ÉS TECHNOLÓGIAI MINISZTÉRIUM ÚNKP-19-2 KÓDSZÁMÚ ÚJ NEMZETI KIVÁLÓSÁG PROGRAMJÁNAK SZAKMAI TÁMOGATÁSÁVAL KÉSZÜLT.

\section{Irodalomjegyzék}

[1] Bitó, J. (2018): „4 percben: amit az RPA-ról tudni érdemes”. Controlling Portal, [online] Elérhető: https://www.controllingportal.hu/amit-az-rpa-rol-tudni-erdemes/ [Megtekintés: 12-01-2020]

[2] Blumné Bán, E. - Zéman, Z. (2014): „Controlling a vezetés szolgálatában. Történeti fejlődés, perspektívák.”. Taylor: gazdálkodás- és szervezéstudományi folyóirat, (6) 1-2. pp. 439-447.

[3] Fenyves, V. (2019): „Controllerekkel szembeni munkaerőpiaci elvárások vizsgálata.” Controller Info $7: 4$ pp. 33-40.

[4] Fenyves V. - Tarnóczi T. (2019): Examination of the expectations of controllers on the labour market CORPORATE OWNERSHIP AND CONTROL $17: 1 \mathrm{pp} .60-70$.

[5] Frey, C. B. - Osborne, M.A. (2013): „The future of employment: how susceptible are jobs to computerisation?” University of Oxford.

[6] Fülep, I. - Nick, G. - Várgedő, R. (2018): „Zászlón a digitalizáció - Ipar 4.0” [online] Elérhető: http://kozszov.org.hu/dokumentumok/UMK 2018/2/07 Ipar 4 0.pdf [Megtekintve: 12-01-2020]

[7] Geissbauer, R. - Vedso, J. - Schrauf, S. (2016): „Industry 4.0: Building the digital enterprise.” PricewaterhouseCoopers LLP, Németország

[8] Heynitz, H.v. - Bremicker, M. - Amadori, D. M. - Reschke, K. (2016): „The factory of the future.” KPMG AG, Németország.

[9] Isensee, J. - Ostrowicz, S. - Reuschenbach, D. (2019): „RPA im Controlling.” Horváth \& Partners, Hamburg, [10] Maczó, K. (2007): „Controlling a gyakorlatban.” Kempelen Farkas Hallgatói Információs Központ. 
[11] Musinszki, Z. (2016): „Ipar 4.0 - költségrendszer 4.0?: Innovációk a költségrendszerekben” Controller Info 4 : 3 pp. 2-9.

[12] Musinszki, Z. - Gyenge, N. - Lipták, K. (2019): „Needs and Expectations - Controllers in the Hungarian Labor Market.” Theory Methodology Practice: Club of Economics in Miskolc 15 : 02 pp. 29-40.

[13] Solti, G. (2013): „Mitől lesz sikeres egy controller? What makes a controller successful?” Controlling Portal, [online] Elérhető: https://www.controllingportal.hu/mitol_lesz_sikeres_egy_controller_/[Megtekintés: 11Jan-2020].

[14] Waelter, A. - Kaplan, B. - Gibson, A. B. - Krumwiede, K. (2018): „Stepping Outside the Box: Elevating the Role of the Controller.” Deloitte Development LLC,

[15] „Finance as Business Partner. „Adding up or adding value” Research: The most important aspects of being a good Business Partner.” PwC 2017 [online] Elérhető: https://www.pwc.nl/nl/assets/documents/pwc-financeas-business-partner-adding-up-or-adding-value-2017.pdf [Megtekintve: 12-01-2020]

[16] „The development phases of data analysis” ICA International Controller Association, 2015. 